\title{
THE INFORMATION SEEKING BEHAVIOUR OF FACULTY MEMBERS IN THE UNIVERSITIES IN ANDHRAPRADESH: A STUDY
}

\author{
THOLKAPPIAN. $\mathrm{S}^{1}$ \& CHANDRAN. $\mathrm{D}^{2}$ \\ ${ }^{1}$ Research Scholar, Department of Library \& Information Science, Sri Venkateswara University \\ Tirupati, Andhra Pradesh India \\ ${ }^{2}$ Professor, Department of Library \& Information Science, Sri Venkateswara University \\ Tirupati, Andhra Pradesh India
}

\begin{abstract}
This study investigates the information seeking behaviour of faculty members in the Universities of Andhra Pradesh. The population of the study is the full time faculty members in Universities in Andhra Pradesh. A structured questionnaire has been used for gathering data from the Universities. The data collected using the questionnaire was analyzed using frequency, bar chart, Weighted Arithmetic Mean (WAM) and percentage for easy interpretation. The research finding shows that the majority of the respondents use the formal sources like Books/Monographs and Journals/Periodicals and informal sources, Conversations with Colleague's and attending the Meetings / Seminar / Conferences / Workshops and the Problems in Seeking Information or information is scattered in too many sources, Unavailability of materials and some of information materials are out dated. The following are recommended in line with the findings of the study: Libraries should improve the collections, and the faculty members should contact the librarians to increase the electronic resources.
\end{abstract}

KEYWORDS: Faculty Members, Information Seeking Behaviour \& Universities in Andhra Pradesh

\section{INTRODUCTION}

Information is essentially a basic need of every human being in addition to air, water, food and shelter. Information becomes an important ingredient in every walk of life. To reduce the thirst for information, users adopt numerous ways and means to access the various channels of communication of information.

Again the use of information is so complex that there cannot be a single system to cope up with the task of effective retrieval without assessing their specific needs. This situation has paved way to the concept of information search and the manner of determining the pattern of search is considered as an information seeking behaviour.

Information is data that have been handled into a meaningful form. This is a grouping of data in an understandable form capable of communication and use; the essence of it is that a meaning has been attached to the raw facts (International Encyclopedia of Information and Library Science, 2003).

Wilson (2000) suggests that information needs are influenced by a variety of factors such as the range of information sources available, the uses to which the information will be put, the contextual, inspiration, professional orientation and distinct characteristics of the user.

Faculty members need information for varied purposes, getting the essential information to meet their needs possess a great experiment for them. This study is therefore aimed at determining the information seeking behaviour of 
faculty members with a view to improve their searching skills, recognize the challenges they face while searching for information and extend possible solutions to them.

\section{OBJECTIVES OF THE STUDY}

Studying the information seeking behaviour of faculty members will empower libraries bring standard services, which will improve the searching skills, teaching and research output of academics in the community.

This study attempts to establish ways of improving the information-seeking behaviour of faculty members. To attain this goal, the study postulates the following objectives:

- To find out the sources of information faculty members are familiar with

- To discover their information needs

- To establish the problems that faculty members encounter in information seeking

\section{LIMITATIONS}

- This study has been limited to the universities of Rayalaseema Region in Andhra Pradesh.

- Further, ithas been confined to regular faculty members of Arts, Science and Humanities working in six selected universities started on or before 2007.

\section{LITERATURE REVIEW}

The literature of information seeking behaviour of faculty members available is greatly broad ranging. An attempt has been made to cover number of works that of the information seeking behaviour. This broad review also includes topics like information seeking of faculty.

Patitungkho, K. and Deshpande, N. J. (2005) in an article report the result of a study of the information seeking behaviour of faculty members of Rajabhat Universities in Bangkok, Thailand. Data were collected by using a questionnaire from seven faculties in Rajabhat Universities. Results show that most of respondents (41) stated their method of seeking information by consulting a knowledgeable person in the field. Two hundred and thirteen respondents (82) seek information for preparing lectures. Fifty-four percent of faculty members access more references from a book. It is revealed that most of the faculty members (57) used textbooks. Seventy four percent of respondents read information materials in Thai and twenty four percent read materials in English. The Internet has been almost universally adopted; they trace materials from the library via the Internet. Google.com was used for searching information by respondents. They frequently use e-mail for communication. It is found that 42 percent of respondents use the ERIC (Education Resources Information Centre) database. The majority of respondents face the common problem while seeking information i.e. unavailability of information.

Suriya, Sangeetha and Nambi (2004) carried out a research work on "Information seeking behaviour of Faculty Members from Government Arts Colleges in Cuddalore District." The purpose of their study was to investigate, how faculty members seek information from the library. It mentions that most of the respondents 61 (38.12 percent) visited the library several times a week to meet their information needs. Regarding the type of search made by the respondents the majority of the respondents 91 (56.87 percent) made their search by subject. 
Shokeen and Kushik (2002) studied about information seeking behaviour of social scientists working in the universities located in Haryana. They reported most of the social scientists visit the library daily. The first preferred method of searching the required information by the social scientists followed by searching through indexing and abstracting periodicals, and citations in articles respectively. The social scientists use current journals followed by books.

Challener(1999) investigated artists and art historians teaching in five liberal arts colleges and three universities. Results found that they need information for teaching. The participants almost all subscribe to art journals, and many read newspapers. They visit libraries frequently, usually more than one library, and unlike previous reports, the majority is willing to ask the librarian for help. A large percentage of both art historians and artists are using computers for teaching. All 27 participants use slides extensively in the classroom, supplemented in most cases by textbooks.

Reneker (1992) investigated the information seeking activities of 31 members of the Stanford University academic community were examined over a two-week period during the 1990-91 academic year. She adopted the naturalistic approach and employed qualitative techniques for the data collection using mainly personal interviews. Informants' perception of their information environment is expressed in positive terms, and there is a close relationship between knowledge of the information environment and the sources used. Information seeking is embedded in the day-to-day activities and relationships of the participants and is triggered both by the articulation of need and availability of information. A large number of needs are satisfied by sources the informants created or organized themselves and by interpersonal information sources. The findings of the study indicated that the action of information seeking originated from a wide variety of needs like personal, professional, entertainment, etc.

Purnima, T.H., and Vikas, Devichongtham (2005).An attempt has been made to study the information needs of the college faculties of Higher Education in Manipur. The study reveals that except for a few colleges/universities, most of the faculties were not aware of the IT, due to lack of infrastructure in their libraries. Questionnaires method was used to collect data from the college and university faculties to understand their information needs and thereby, suggest application of ICT to all the colleges and University of Manipur.

\section{METHODOLOGY}

A Survey research method is used to carry out this study because of its large population. The instrument used for data collection in this study is questionnaire. The target population of this study comprises the full time faculty members of the universities of Andhra Pradesh.

A total 680 out of 838 regular faculty members working in the selected six universities taken for the study of Andhra Pradesh, have responded and the response rate is 81 , which is presented in Table 1.1 
Table 1.1: Distribution of Questionnaires and Responses

\begin{tabular}{|r|l|c|c|c|}
\hline $\begin{array}{r}\text { S. } \\
\text { No }\end{array}$ & Name of the University & $\begin{array}{c}\text { Questionnaires } \\
\text { Distributed }\end{array}$ & $\begin{array}{c}\text { Response } \\
\text { Received }\end{array}$ & Percentage \\
\hline 1 & Sri VenkateswaraUniversity(SVU), Tirupati., & 335 & 280 & 83.6 \\
\hline 2 & Dravidian University (DU), Kuppam. & 87 & 71 & 81.6 \\
\hline 3 & $\begin{array}{l}\text { Sri PadmavathiMahilaVisvavidyalayam } \\
\text { (Women's University)(SPMV), Tirupati. }\end{array}$ & 120 & 106 & 88.3 \\
\hline 4 & Yogi VemanaUniversity(YVU), Kadapa. & 48 & 39 & 81.3 \\
\hline 5 & Rashtriya Sanskrit Vidyapeetha(R SV), Tirupati. & 70 & 49 & 70.0 \\
\hline 6 & $\begin{array}{l}\text { Sri KrishnadevarayaUniversity(SKU), } \\
\text { Anantapur. }\end{array}$ & 178 & 135 & 75.8 \\
\hline & Total & $\mathbf{8 3 8}$ & $\mathbf{6 8 0}$ & $\mathbf{8 1 . 0}$ \\
\hline
\end{tabular}

\section{DISCUSSIONS OF FINDINGS}

\section{Library Visit}

All the Faculty members of the universities in Andhra Pradesh are University Library Members, and can visit the library at free of cost. It is evident from the Table $\mathbf{1 . 2}$ that most of the respondents (28.7\%) visit the library every day, following that $21.6 \%$ visit more than once in a week, $17.6 \%$ visited once in a week, $15.7 \%$ visit occasionally, $11.8 \%$ visit once in a month and only $4.6 \%$ visit once in a fortnight. The pictorial representation is shown in the Figure. 1.1

Table 1.2: Frequency of Library Visit by the Respondents

\begin{tabular}{|c|c|c|c|c|c|c|c|c|}
\hline \multirow[b]{2}{*}{$\begin{array}{r}\text { S. } \\
\text { No. }\end{array}$} & \multirow[b]{2}{*}{$\begin{array}{l}\text { Name of the } \\
\text { University }\end{array}$} & \multicolumn{6}{|c|}{ Frequency of Visiting the Library } & \multirow[b]{2}{*}{ Total } \\
\hline & & $\begin{array}{l}\text { Every } \\
\text { Day }\end{array}$ & $\begin{array}{l}\text { Once in a } \\
\text { Week }\end{array}$ & $\begin{array}{c}\text { More } \\
\text { than once } \\
\text { in a week }\end{array}$ & $\begin{array}{c}\text { Once in a } \\
\text { Fortnight }\end{array}$ & $\begin{array}{l}\text { Once in } \\
\text { a Month }\end{array}$ & Occasionally & \\
\hline 1 & SVU, Tirupathi & 76 (11.2) & $\begin{array}{l}48 \\
(7)\end{array}$ & $\begin{array}{c}57 \\
(8.4) \\
\end{array}$ & $\begin{array}{l}14 \\
(2)\end{array}$ & $\begin{array}{c}36 \\
(5.3) \\
\end{array}$ & $\begin{array}{c}49 \\
(7.2)\end{array}$ & $\begin{array}{c}280 \\
(41.1)\end{array}$ \\
\hline 2 & DU, Kuppam. & $\begin{array}{c}28 \\
(4.1)\end{array}$ & $\begin{array}{c}11 \\
(1.6)\end{array}$ & $\begin{array}{l}14 \\
(2)\end{array}$ & $\begin{array}{c}3 \\
(0.4)\end{array}$ & $\begin{array}{c}8 \\
(1.2)\end{array}$ & $\begin{array}{c}7 \\
(1) \\
\end{array}$ & $\begin{array}{c}71 \\
(10.4)\end{array}$ \\
\hline 3 & SPMV, Tirupati. & $\begin{array}{c}26 \\
(3.8) \\
\end{array}$ & $\begin{array}{c}19 \\
(2.8) \\
\end{array}$ & $\begin{array}{c}27 \\
(3.9) \\
\end{array}$ & $\begin{array}{c}4 \\
(0.6) \\
\end{array}$ & $\begin{array}{l}14 \\
(2)\end{array}$ & $\begin{array}{c}16 \\
(2.4) \\
\end{array}$ & $\begin{array}{c}106 \\
(15.5) \\
\end{array}$ \\
\hline 4 & YVU, Kadapa. & $\begin{array}{c}8 \\
(1.2)\end{array}$ & $\begin{array}{c}8 \\
(1.2)\end{array}$ & $\begin{array}{c}10 \\
(1.4)\end{array}$ & $\begin{array}{c}1 \\
(0.1)\end{array}$ & $\begin{array}{c}4 \\
(0.6)\end{array}$ & $\begin{array}{c}8 \\
(1.2)\end{array}$ & $\begin{array}{c}39 \\
(5.7)\end{array}$ \\
\hline 5 & R SV,Tirupati. & $\begin{array}{c}17 \\
(2.5) \\
\end{array}$ & $\begin{array}{c}8 \\
(1.2) \\
\end{array}$ & $\begin{array}{c}9 \\
(1.3) \\
\end{array}$ & $\begin{array}{c}3 \\
(0.4) \\
\end{array}$ & $\begin{array}{c}4 \\
(0.6) \\
\end{array}$ & $\begin{array}{c}8 \\
(1.2) \\
\end{array}$ & $\begin{array}{c}49 \\
(7.2) \\
\end{array}$ \\
\hline 6 & SKU, Anantapur. & $\begin{array}{c}40 \\
(5.9)\end{array}$ & $\begin{array}{c}26 \\
(3.8)\end{array}$ & $\begin{array}{c}30 \\
(4.4)\end{array}$ & $\begin{array}{c}6 \\
(0.9)\end{array}$ & $\begin{array}{l}14 \\
(2)\end{array}$ & $\begin{array}{c}19 \\
(2.8)\end{array}$ & $\begin{array}{c}135 \\
(19.9)\end{array}$ \\
\hline & Total & $\begin{array}{c}195 \\
(28.7)\end{array}$ & $\begin{array}{c}120 \\
(17.6)\end{array}$ & $\begin{array}{c}147 \\
(21.6)\end{array}$ & $\begin{array}{c}31 \\
(4.6)\end{array}$ & $\begin{array}{c}80 \\
(11.8) \\
\end{array}$ & $\begin{array}{c}107 \\
(15.7)\end{array}$ & $\begin{array}{r}680 \\
(100)\end{array}$ \\
\hline
\end{tabular}

(Figures in the Parenthesis indicate percentage) 


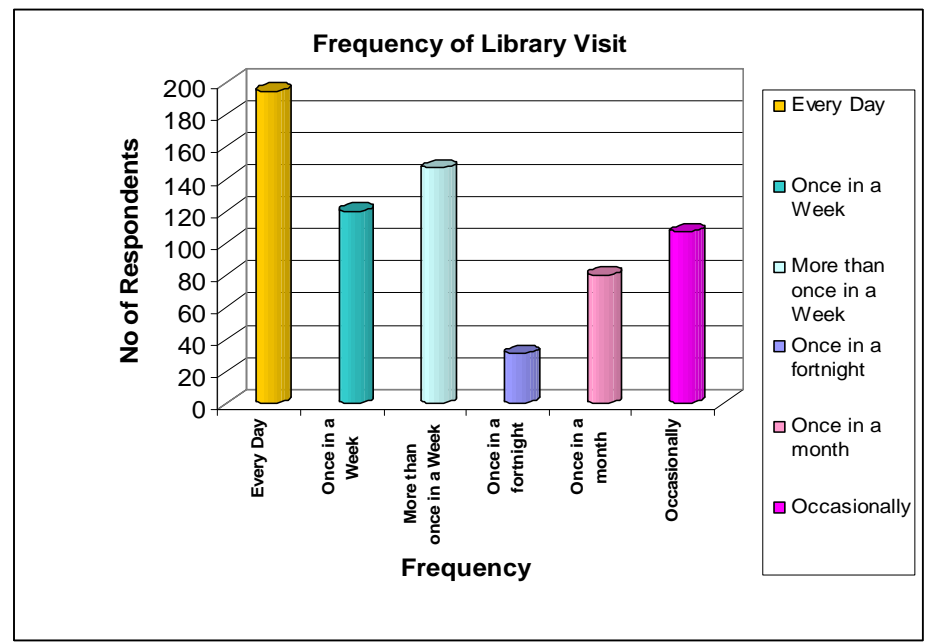

Figure 1.1: Frequency of Library Visit by the Respondents

Formal Sources used by the Respondents

The data in Table 1.3 reveals the 5-point scaling technique analysis results for the formal sources used by the respondents, names Mostly Used, Occasionally Used, Rarely Used, and Not Used and the diagrammatic representation is given in the Figure. 1.2.

It is found that, from the Table 4.8 majority are using the formal sources mostly like, Books/Monographs (80.3\%), Journals/Periodicals (65.9\%), Reference Sources (41.3\%), Patents (2.4\%), Reports (10.7\%), Standards (19.1\%), Online Journals (37.8\%), E-Books (27.9\%), Internet (48.4\%), Audio/Video (14.1\%), CD-ROM/DVD (19.3\%), Review Articles (40\%), and Thesis and Dissertations (31.2\%).

Table 1.3: Formal Sources used by the Respondents

\begin{tabular}{|c|c|c|c|c|c|c|c|}
\hline $\begin{array}{c}\text { S. } \\
\text { No. }\end{array}$ & Formal Sources & 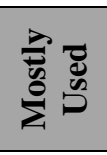 & 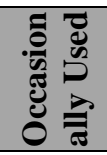 & 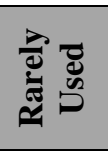 & 忞总 & $\sum_{i}$ & 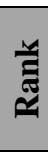 \\
\hline 1 & Books/Monographs & $\begin{array}{c}546 \\
(80.3)\end{array}$ & $\begin{array}{c}70 \\
(10.3)\end{array}$ & $\begin{array}{c}63 \\
(9.3)\end{array}$ & $\begin{array}{c}1 \\
(0.1)\end{array}$ & 630.25 & 1 \\
\hline 2 & Journals / Periodicals & $\begin{array}{c}448 \\
(65.9) \\
\end{array}$ & $\begin{array}{c}154 \\
(22.6) \\
\end{array}$ & $\begin{array}{c}62 \\
(9.1) \\
\end{array}$ & $\begin{array}{c}16 \\
(2.4) \\
\end{array}$ & 598.50 & 2 \\
\hline 3 & $\begin{array}{l}\text { Reference Sources (such as Bibliographies, } \\
\text { Databases, Handbooks, Indexing \& Abstracting } \\
\text { Sourcesetc.) }\end{array}$ & $\begin{array}{c}281 \\
(41.3)\end{array}$ & $\begin{array}{c}173 \\
(25.4)\end{array}$ & $\begin{array}{c}146 \\
(21.5)\end{array}$ & $\begin{array}{c}80 \\
(11.8)\end{array}$ & 503.75 & 3 \\
\hline 4 & Patents & $\begin{array}{c}16 \\
(2.4)\end{array}$ & $\begin{array}{c}69 \\
(10.1)\end{array}$ & $\begin{array}{c}459 \\
(67.5)\end{array}$ & $\begin{array}{l}136 \\
(20)\end{array}$ & 331.25 & 13 \\
\hline 5 & Reports & $\begin{array}{c}73 \\
(10.7)\end{array}$ & $\begin{array}{c}206 \\
(30.3) \\
\end{array}$ & $\begin{array}{c}292 \\
(42.9)\end{array}$ & $\begin{array}{l}109 \\
(16) \\
\end{array}$ & 400.75 & 11 \\
\hline 6 & Standards & $\begin{array}{c}130 \\
(19.1)\end{array}$ & $\begin{array}{c}132 \\
(19.4)\end{array}$ & $\begin{array}{c}278 \\
(40.9)\end{array}$ & $\begin{array}{c}140 \\
(20.6)\end{array}$ & 403.00 & 10 \\
\hline 7 & Online Journals & $\begin{array}{c}257 \\
(37.8)\end{array}$ & $\begin{array}{l}129 \\
(19)\end{array}$ & $\begin{array}{c}169 \\
(24.9)\end{array}$ & $\begin{array}{c}125 \\
(18.4)\end{array}$ & 469.50 & 7 \\
\hline 8 & E-Books & $\begin{array}{c}190 \\
(27.9)\end{array}$ & $\begin{array}{c}125 \\
(18.4)\end{array}$ & $\begin{array}{c}215 \\
(31.6)\end{array}$ & $\begin{array}{c}150 \\
(22.1)\end{array}$ & 428.75 & 8 \\
\hline 9 & Internet & $\begin{array}{c}329 \\
(48.4) \\
\end{array}$ & $\begin{array}{c}88 \\
(12.9) \\
\end{array}$ & $\begin{array}{c}148 \\
(21.8) \\
\end{array}$ & $\begin{array}{c}115 \\
(16.9) \\
\end{array}$ & 497.75 & 4 \\
\hline 10 & Audio / Video & $\begin{array}{c}96 \\
(14.1)\end{array}$ & $\begin{array}{c}135 \\
(19.9)\end{array}$ & $\begin{array}{c}284 \\
(41.8)\end{array}$ & $\begin{array}{c}165 \\
24.3)\end{array}$ & 380.50 & 12 \\
\hline
\end{tabular}




\begin{tabular}{|c|c|c|c|c|c|c|c|}
\hline \multicolumn{8}{|c|}{ Table 1.3: Contd,. } \\
\hline 11 & CD-ROM / DVD & $\begin{array}{c}131 \\
(19.3)\end{array}$ & $\begin{array}{c}150 \\
(22.1)\end{array}$ & $\begin{array}{c}274 \\
(40.3)\end{array}$ & $\begin{array}{c}125 \\
(18.4)\end{array}$ & 411.75 & 9 \\
\hline 12 & Review Articles & $\begin{array}{l}272 \\
(40)\end{array}$ & $\begin{array}{l}143 \\
(21)\end{array}$ & $\begin{array}{c}174 \\
(25.6)\end{array}$ & $\begin{array}{c}91 \\
(13.4)\end{array}$ & 489.00 & 5 \\
\hline 13 & Theses and Dissertations & $\begin{array}{c}212 \\
(31.2)\end{array}$ & $\begin{array}{c}241 \\
(35.4)\end{array}$ & $\begin{array}{c}144 \\
(21.2)\end{array}$ & $\begin{array}{c}83 \\
(12.2)\end{array}$ & 485.50 & 6 \\
\hline
\end{tabular}

(Figures in the Parenthesis indicate percentage)

The WAM (Weighted Average Mean) values according to the ranking order about the utilization of formal sources by the respondents are as follows

- Rank 1. Books/Monographs (630.25)

- $\quad$ Rank 2. Journals / Periodicals (598.50)

- Rank 3. Reference Sources (503.75)

- $\quad$ Rank 4. Internet

$(497.75)$

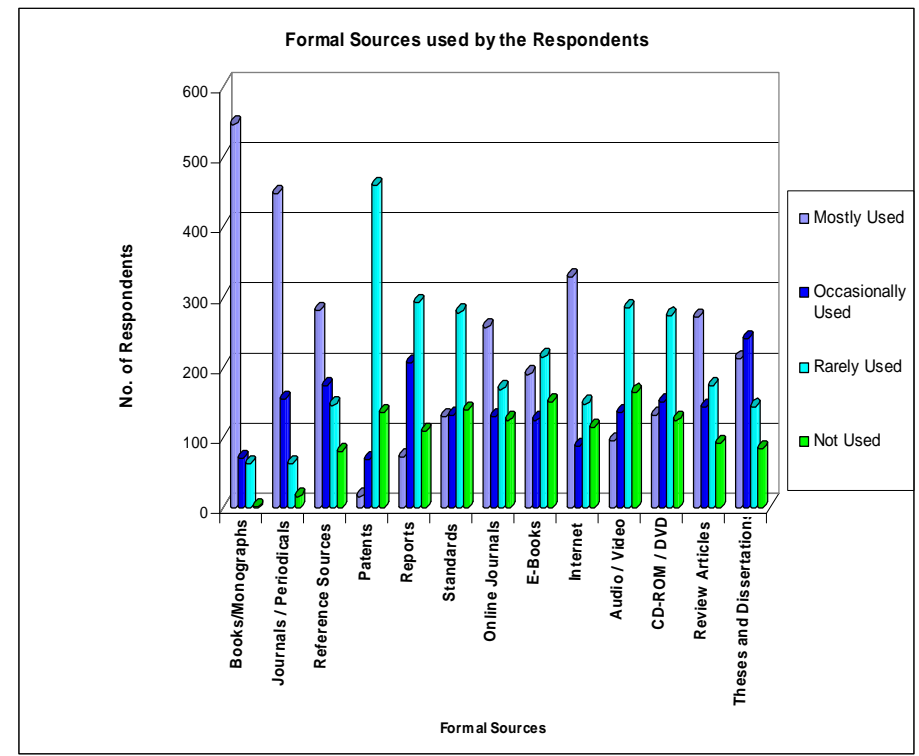

Figure 1.2: Formal Sources used by the Respondents

\section{Informal Sources used by the Respondents}

The data in Table 1.4 presents the 5-point scaling technique analysis results for informal sources used by the respondents, names Mostly Used, Occasionally Used, Rarely Used, and Not Used and the diagrammatic representation is given in the Figure 1.3.

Table 1.4 reveals that the majority are using the Informal Sources mostly like, E-mail (58.7), Face-to-Face Discussions (40.6\%), Conversations with Colleagues (53.7\%), Meetings / Seminar / Conferences / Workshops (45.9\%), Consult Research Supervisor (23.7\%), Discussion Forum.(17.1\%), Previous Knowledge (44\%), Private Correspondences (4.7\%), Discussion with Librarian (8.8\%), and Consult Knowledgeable Person (44.9\%). 
Table 1.4: Informal Sources used by the Respondents

\begin{tabular}{|c|c|c|c|c|c|c|c|}
\hline S. No. & Informal Sources & 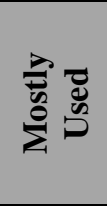 & 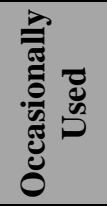 & 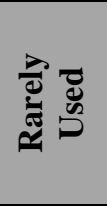 & 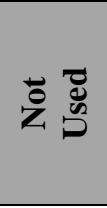 & $\sum_{i}$ & 劵 \\
\hline 1 & E-mail & $\begin{array}{c}399 \\
(58.7) \\
\end{array}$ & $\begin{array}{c}93 \\
(13.7) \\
\end{array}$ & $\begin{array}{c}112 \\
(16.5)\end{array}$ & $\begin{array}{c}76 \\
(11.2)\end{array}$ & 543.75 & 3 \\
\hline 2 & Face-to-Face discussions & $\begin{array}{c}276 \\
(40.6) \\
\end{array}$ & $\begin{array}{c}229 \\
(33.7) \\
\end{array}$ & $\begin{array}{c}111 \\
(16.3) \\
\end{array}$ & $\begin{array}{c}64 \\
(9.4) \\
\end{array}$ & 519.25 & 5 \\
\hline 3 & Conversations with colleagues & $\begin{array}{c}365 \\
(53.7) \\
\end{array}$ & $\begin{array}{c}249 \\
(36.6) \\
\end{array}$ & $\begin{array}{c}63 \\
(9.3) \\
\end{array}$ & $\begin{array}{c}3 \\
(.4) \\
\end{array}$ & 584.00 & 1 \\
\hline 4 & Meetings / Seminar / Conferences / Workshops & $\begin{array}{c}312 \\
(45.9) \\
\end{array}$ & $\begin{array}{c}273 \\
(40.1) \\
\end{array}$ & $\begin{array}{c}54 \\
(7.9) \\
\end{array}$ & $\begin{array}{l}41 \\
(6) \\
\end{array}$ & 554.00 & 2 \\
\hline 5 & Consult Research Supervisor & $\begin{array}{c}161 \\
(23.7)\end{array}$ & $\begin{array}{c}293 \\
(43.1)\end{array}$ & $\begin{array}{c}160 \\
(23.5)\end{array}$ & $\begin{array}{c}66 \\
(9.7)\end{array}$ & 477.25 & 7 \\
\hline 6 & Discussion forum. & $\begin{array}{c}116 \\
(17.1) \\
\end{array}$ & $\begin{array}{c}258 \\
(37.9) \\
\end{array}$ & $\begin{array}{c}215 \\
(31.6) \\
\end{array}$ & $\begin{array}{c}91 \\
(13.4)\end{array}$ & 439.75 & 8 \\
\hline 7 & Previous Knowledge & $\begin{array}{l}299 \\
(44)\end{array}$ & $\begin{array}{c}174 \\
(25.5)\end{array}$ & $\begin{array}{c}99 \\
(14.6)\end{array}$ & $\begin{array}{c}108 \\
(15.9)\end{array}$ & 506.00 & 6 \\
\hline 8 & Private Correspondences & $\begin{array}{c}32 \\
(4.7)\end{array}$ & $\begin{array}{c}252 \\
(37.1) \\
\end{array}$ & $\begin{array}{c}327 \\
(48.1) \\
\end{array}$ & $\begin{array}{c}69 \\
(10.1) \\
\end{array}$ & 401.75 & 9 \\
\hline 9 & Discussion with Librarian & $\begin{array}{c}60 \\
(8.8)\end{array}$ & $\begin{array}{c}216 \\
(31.8)\end{array}$ & $\begin{array}{l}313 \\
(46)\end{array}$ & $\begin{array}{c}91 \\
(13.4)\end{array}$ & 401.25 & 10 \\
\hline 10 & Consult knowledgeable person & $\begin{array}{c}305 \\
(44.9)\end{array}$ & $\begin{array}{c}217 \\
(31.9)\end{array}$ & $\begin{array}{c}134 \\
(19.7)\end{array}$ & $\begin{array}{c}24 \\
(3.5)\end{array}$ & 540.75 & 4 \\
\hline
\end{tabular}

(Figures in the Parenthesis indicate percentage)

The WAM (Weighted Average Mean) values according to the ranking order about the utilization of informal sources by the respondents are as follows:

- Rank 1 Conversations with colleague's

$(584.00)$

- Rank 2 Meetings / Seminar / Conferences / Workshops (554.00)

- Rank 3 E-mail $(543.75)$

- Rank 4 Consult knowledgeable person $(540.75)$

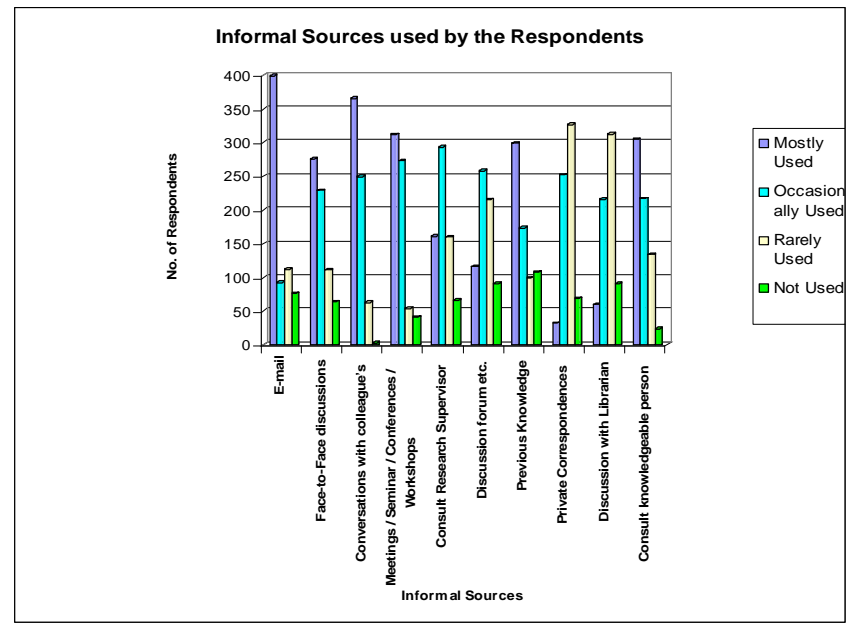

Figure 1.3: Informal Sources used by the Respondents 


\section{Problems in Seeking Information}

The data in the Table $\mathbf{1 . 5}$ reveals that some of the faculty members were facing problem in seeking information. A total of nine problems are identified in this study, and the analysis is as follows:

\section{Weighted Arithmetic Mean for the Problems Faced while seeking Information}

Table 1.5 presents the WAM values on five-point scaling for the nine variables according to the ranking order. The problems faced have been ranked using WAM. The rank of the variables is given below. The diagrammatic illustration is given below in the Figure.1.4.

- Rank 1 Information scattered in too many sources $\quad 480.50$

- Rank 2 Material not available $\quad 454.50$

- $\quad$ Rank 3 Some of information materials are old $\quad 446.00$

Table 1.5: Problems Faced while Seeking Information by the Respondents

\begin{tabular}{|c|l|c|c|c|c|c|}
\hline $\begin{array}{c}\text { S. } \\
\text { No. }\end{array}$ & Problems Faced While Seeking Information & $\begin{array}{c}\text { Variable } \\
\text { Code }\end{array}$ & Yes & No & WAM & Rank \\
\hline 1 & Material not available & A & $\begin{array}{c}229 \\
(33.7)\end{array}$ & $\begin{array}{c}451 \\
(66.3)\end{array}$ & $\mathbf{4 5 4 . 5 0}$ & $\mathbf{2}$ \\
\hline 2 & Library staff is unwilling for help & B & $\begin{array}{c}55 \\
(8.1)\end{array}$ & $\begin{array}{c}625 \\
(91.9)\end{array}$ & $\mathbf{3 6 7 . 5 0}$ & $\mathbf{7}$ \\
\hline 3 & Information scattered in too many sources & $\mathrm{C}$ & $\begin{array}{c}281 \\
(41.3)\end{array}$ & $\begin{array}{c}399 \\
(58.7)\end{array}$ & $\mathbf{4 8 0 . 5 0}$ & $\mathbf{1}$ \\
\hline 4 & Lack of time & $\mathrm{D}$ & $\begin{array}{c}205 \\
(30.1)\end{array}$ & $\begin{array}{c}475 \\
(69.9)\end{array}$ & $\mathbf{4 4 2 . 5 0}$ & $\mathbf{4}$ \\
\hline 5 & Do not know how to use the catalogue & $\mathrm{E}$ & $\begin{array}{c}55 \\
(8.1)\end{array}$ & $\begin{array}{c}625 \\
(91.9)\end{array}$ & $\mathbf{3 6 7 . 5 0}$ & $\mathbf{7}$ \\
\hline 6 & Lack of knowledge in using the library & $\mathrm{F}$ & $\begin{array}{c}48 \\
(7.1)\end{array}$ & $\begin{array}{c}632 \\
(92.9)\end{array}$ & $\mathbf{3 6 4 . 0 0}$ & $\mathbf{8}$ \\
\hline 7 & Incomplete information materials & $\mathrm{G}$ & $\begin{array}{c}111 \\
(16.3)\end{array}$ & $\begin{array}{c}569 \\
(83.7)\end{array}$ & $\mathbf{3 9 5 . 5 0}$ & $\mathbf{5}$ \\
\hline 8 & Information sources not located & $\mathrm{H}$ & $\begin{array}{c}84 \\
(12.4)\end{array}$ & $\begin{array}{c}596 \\
(87.6)\end{array}$ & $\mathbf{3 8 2 . 0 0}$ & $\mathbf{6}$ \\
\hline 9 & Some of information materials are old & $\mathrm{I}$ & $\begin{array}{c}212 \\
(31.2)\end{array}$ & $\begin{array}{c}468 \\
(68.8)\end{array}$ & $\mathbf{4 4 6 . 0 0}$ & $\mathbf{3}$ \\
\hline
\end{tabular}

(Figures in the Parenthesis indicate percentage)

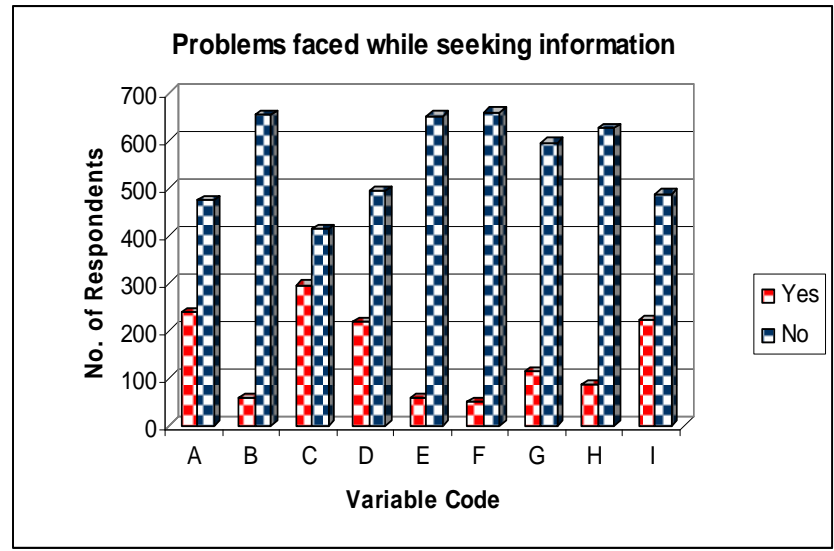

Figure 1.4: Problems Faced While Seeking Information by the Respondents 


\section{CONCLUSIONS}

The study investigated the information needs and information seeking behaviour of law faculty members at the Dr. Ambedkar Law University. It was found that respondents used a variety of information sources for teaching and research. Books, law reports and statutes were considered more important. It is interesting to note that, although respondents perceived he Dr. Ambedkar Law University

The study has investigated the information seeking behaviour of faculty members in the selected six Universities located in Rayalaseema Region, Andhra Pradesh. It is found that the respondents have used a variety of formal and informal information sources for teaching and research. Formal Sources like Books/Monographs and Journals/Periodicals and informal sources like E-mail and Conversations with Colleagues are considered more important. The study reveals that the respondents have felt that the available resources are not sufficient and some materials available are old. It may be due to the lack of awareness about their obtainability, inappropriate selection of materials or unfamiliarity with these resources. Likewise, it is also noted that e-mail is the most widespread Internet application, but other Internet-based services and applications are only used by a limited number of respondents. This is a matter of worry, as presently, electronic information sources and Internet are considered extremely important tools for effective teaching and research. Therefore, it is suggested to review the electronic resources in the university libraries and at the same time, extensive library promotion and user education programs can also aid the users effectively.

\section{REFERENCES}

1. Challener, J. (1999). Information seeking behavior of professors of art history and studio art. Master Dissertation, School of Library and Information Science, Kent State University, Retrieved June, 5th 2010, from https://eric.ed.gov/?id=ED435405.

2. International Encyclopedia of Information and Library Science (2003). Information. London: Routledge publisher (p.244-245).

3. Patitungkho, K and Deshpande, N J (2005).Information Seeking Behaviour of Faculty Members of Rajabhat Universities in Bangkok, Webology.Vol.2, No.4 p.1-12.

4. Purnima, T.H, and Vikas, Devichongtham (2005). Information needs in higher education : A Study of college faculties in Manipur. ILA Bulletin, Vol.41, No.2: p.16-19.

5. Reneker, M. (1992). Information - seeking among members of an academic community. DLS thesis. New Yourk: Columbia University.

6. Shokeen, A and Kushik, S K (2002). Information Seeking Behaviour of social scientists of Haryana universities. Library Herald, Vol.40, No.1:p.8-11.

7. Suriya, M., Sangeetha, G., and Nambi, M A (2004).Information-seeking behavior of faculty members from government arts colleges in cuddaloredistrict.In:Kaul, N.K. and Patil, S.K. (Eds), Library and Information Networking (NACLIN 2004). New Delhi, 2004:p.285-292.

8. Wilson T D (2000). Recent trends in user studies: Action research and qualitative methods. Information Research 5(3).Retrieved from http://www.informationr.net/ir/5-3/paper76.html 
